\title{
Risk Factors of Recidivism: Lessons from Central Prison in Kumasi, Ghana
}

\author{
Christine Glover ${ }^{1}$, Jacob Obodai², James Mabery Forkuor ${ }^{1}$, Abena Korang Acheampong Abaitey ${ }^{2}$ \\ ${ }^{1}$ Department of Theology, Christian Service University College, Kumasi, Ghana \\ ${ }^{2}$ Department of Planning, Christian Service University College, Kumasi, Ghana \\ Email: jacobobodai@gmail.com
}

How to cite this paper: Glover, C., Obodai, J., Forkuor, J.M. and Abaitey, A.K.A. (2018) Risk Factors of Recidivism: Lessons from Central Prison in Kumasi, Ghana. Open Access Library Journal, 5: e4744.

https://doi.org/10.4236/oalib.1104744

Received: June 26, 2018

Accepted: October 21, 2018

Published: October 24, 2018

Copyright (c) 2018 by authors and Open Access Library Inc.

This work is licensed under the Creative Commons Attribution International License (CC BY 4.0).

http://creativecommons.org/licenses/by/4.0/

(c) (i) Open Access

\begin{abstract}
Recidivism is a major problem faced by all countries in the world and entails a tendency to relapse into a previous behavior (criminal behavior in the context of this study). Using a qualitative approach, this study examined the risk factors of recidivism in Kumasi Central Prisons. Purposive sampling method was espoused to gather data from thirty prison inmates and key informants including prison ministry evangelists, prison officers and families of ex-offenders. The study found inadequate support from family, stigma by society, lack of job opportunities, lack of income and accommodation as the most prominent risk factors of recidivism among prison inmates in the $\mathrm{Ku}$ masi Central Prisons despite the important roles played by Christian churches through their prison ministries. The study therefore among others recommends that prison ministry must go beyond the prison walls by eliciting the active participation of family, community and society in the physical and spiritual care for the ex-offender.
\end{abstract}

\section{Subject Areas}

Sociology

\section{Keywords}

Recidivism, Prison, Risk Factor, Central Prison, Ghana

\section{Introduction}

The major challenge with prison work is the situation called recidivism. The word "recidivism" is derived from the Latin root words "re", meaning "back" and "caedere" meaning "to fall" - or literally "to fall back." Therefore, recidivism means a "tendency to relapse into a previous condition or mode of behavior; es- 
pecially relapse into criminal behavior" [1]. Recidivism is a worldwide problem facing all governments and stakeholders concerned with the welfare of ex-convicts. In 2012, a newspaper article published that recidivism rate in the United States was hovering around 70\% [2]. A statistical table on rates of recidivism on selected countries indicates that some western European countries such as United Kingdom, Scotland and Ireland have equally high rate of recidivism as the United States of America-as indicated in Table 1 [3].

In Africa, due to difficulty with keeping records, available statistics on recidivism are difficult to come by but generally, estimates are believed to be very high. The recidivism percentage rate in Ghana had been fluctuating from 21\% in 2004 through to $19.3 \%$ in 2008 and to $22.2 \%$ in 2011 [4]. A former Deputy Minister for Interior, James Agalga noted that recidivism is on the increase in Ghana due to the feeling of rejection by ex-convicts [5].

Information as provided by International Centre for Prison Studies on Ghana prisons indicates that in November 2016, the total prison population (inclusive of pre-trial detainees) stood at 13,309 as against official capacity of prison system which is 9875 [6]. The same source has it that in November 2016, the prison population rate was 48 per every 100,000 of national population based on an estimated population of 27.73 million. Finally, the source informed that prison population has increased steadily from 9507 in the year 2000 to 14,599 in 2014.

In mitigating against the ever-increasing incarceration rate, a former Minister of Justice and Attorney General initiated the Justice for All Programme in 2007. The programme is aimed at taking the justice delivery system to the doorstep of the marginalized and reduce congestion at the various prisons in the country [7] It is noted that since the inception of the programme in 2007, a total of 3293 inmates had appeared before the programme and out of that number, 672 were discharged and 985 granted bail, 135 convicted and others referred to the psychiatric hospitals for medical attention [7].

Notwithstanding the above stated programme together with other programmes aimed at reforming and preparing the offender for the outside world; such as trade training, educational programmes, sports, counseling and chaplaincy activities, a lot more ex-convicts become recidivists.

Table 1. Selected rates of recidivism.

\begin{tabular}{cc}
\hline Country & Percentage rate of Recidivism \\
\hline Australia & $39 \%$ \\
Ireland & $62 \%$ \\
Japan & $43 \%$ \\
Scotland & $50 \%$ \\
United Kingdom (England and Wales) & $46 \%$ \\
United States & $52 \%$
\end{tabular}

Source: Deady, 2014. 
This study aimed exploring the risk factors that accounts for the high rate of recidivism despite the various policies and interventions and the role the church in reducing the high rate of recidivism.

\section{Prison Ministry and Recidivism: A Theoretical Review}

Some literature exist which informs from their empirical investigations that Prison Ministry Programs have some effects on recidivists both prior to and after release from prison with some indicating no effect at all [8] [9] [10] [11]. Though some level of success is chalked by these programs, the researchers; from their findings indicated that the degree of impact it made on recidivists were rather minimal. Research on the impact of Prison Ministry program on recidivism carried out on two most prominent Prison Ministry Organizations and evaluation report on Florida faith based prison institutions, all in the United States of America are discussed below.

\subsection{Prison Fellowship}

Prison Fellowship is a non-profit religious ministry to prisoners, ex-prisoners, crime victims and their families. It was founded in 1976 by Charles Colson. The organization has more than fifty thousand trained volunteers undertaking religious programming such as bible studies and seminars in most prisons in the United States of America [12]. Byron [12] undertook a study in the mid-1990s to determine the relationship if any between Prison Fellowship religious programming and recidivism. The study was undertaken in 4 prisons in the state of New York with a sample of 201 inmates enrolled on Prison Fellowship programs and a control group of 40,000 inmates not on the religious program. The follow up study period on those who were discharged lasted for 8 years. At the end of the stated study period, the findings were that there was no difference between Prison Fellowship and non-Prison Fellowship groups on either measure of recidivism (that is re-arrest and re-imprisonment) throughout the 8 year follow up period. However, those who actively participated in the Prison Fellowship bible studies were least likely to be re-arrested and re-imprisoned between 2 to 3 years after release. But the probability that those who participated in the faith program would not be rearrested or re-imprisoned reduced considerably from the fourth year through to the eighth year.

\subsection{Inner Change Freedom Initiative}

Prison Fellowship, with the full support of Texas Department of Criminal Justice (TDCJ) launched the Inner Change Freedom Initiative program in April 1997. This program was expressly Christian in orientation; a faith based pre-release program. The components of the program included education, work, life skills, values restructuring, and one-on-one mentoring in an environment where religious instructions permeates all aspects of the prison environment. A study was undertaken to specifically track the 2-year post release recidivism rates for those prisoners that entered the Inner Change Freedom Initiative program from April 
1997 through to January 1999 and were released from prison prior to September 1, 2000. A sample size of 177 inmates on the program as against 1754 inmates to serve as comparism group was used for the study. At the end of the 2-year study period, the findings were that $17.3 \%$ who successfully completed the said religious program as against $35 \%$ of the matched comparism group were arrested during the 2 -year post release period. Also, $8 \%$ of the religious program graduates and $20.3 \%$ of the matched comparism group were imprisoned during the stated post release period. Other findings from the study were that mentor contacts were associated with lower rates of recidivism. Another was that completing the religious program and continued pre and post mentoring were core elements to both the offender's transformation and rehabilitation.

However, the lack of post release accountability via mentors and congregations, the decision of the program participants to isolate themselves from those that could benefit them and the tendency to not accept personal responsibility for poor decision making were factors associated with recidivism [8].

\subsection{Kairos Prison Ministry}

Kairos Prison Ministry was established in the fall of 1976 by 9 old men. Kairos is a Greek word meaning "God's special time." The ministry has three main programs. The first program is named Kairos inside which focuses on developing a Christian community inside prisons for both male and female. The second program is named Kairos outside which is directed at women whose loved ones are incarcerated. The third program is named Kairos touch which is directed atthe youth in prison aged 25 years and below. The mission of the ministry is to share the transforming love and forgiveness of Jesus Christ to impact the hearts and lives of incarcerated women, men and youth as well as their families, to become loving and productive citizens of their families. It has branches in 10 different countries serving about 472 communities and prisons.

In a medium security prison in Australia, a study was undertaken with the purpose to examine the likely effects of the Kairos Christian religious program on the risk of re-offending. The study covered the areas of criminal thinking, empathy, self-reflection, and forgiveness of self. A sample of 20 participants on the Kairos program were chosen as against 18 in a control group. The finding from the study was that few statistically significant changes were observed from pre-test to post-test between those that completed the Kairos short course and the control participants [9]. The three different researches undertaken on the impact of Prison Ministry on recidivism did not rule out Prison Ministry as not making any impact at all. The contention was rather on the degree and extent of impact. Significant was the fact that those who actively participated in the bible study were least likely to re-offend.

\subsection{Florida Faith and Character Based Institute}

The state of Florida was the first among the states in the United States of America to dedicate an entirely publicly run prison facility to an entirely faith based 
institution. This took place on $24^{\text {th }}$ December, 2003 [11]. The initial prison facilities were Lawtey, a male prison and Hillsborough, a female prison. The mission of the Faith and Character Based program is to offer a wide range of religious and character focused activities to Florida inmates interested in personal growth and character development. The goals of the program are inmate rehabilitation, successful reintegration of inmates into the community, reduction of recidivism as well as the improvement of institutional security and provision of wide range of religious accommodation for inmates [10]. In mate participation in the program is voluntary and those that choose to participate must meet the requirements for participation. These are participation in one program session a week, participation in religious education classes, joining small group studies, involvement in character development programs and educational or vocational training. The essential characteristics of the program are that eligibility to join the program is not based on the inmate's religious faith or lack of it. State funds are not expended on religious programming or materials and each program is autonomous.

A study was carried out on 189 male inmates participating in the program and the same number for those who were not participants in the program. The average time for those participating in the program to be re-imprisoned during the study was 371 days while the average for the male comparison group was 262 days. None of the 189 male inmates in the faith program were reimprisoned within 6 months of their release. But 4 of the 189 in the comparison group were reimprisonment within 6 months of their release. Though the differences between the main and comparison groups of study were not statistically significant, the fact remains that those involved in the faith program had lower rates of re-imprisonment than those who were not part of the program. Also, the time period of re-arrest and imprisonment was much longer in favor of those in the program than those not in the program [10].

In a separate evaluation undertaken in 2009, the findings were that inmates released from the Faith and Character based institutions have shown somewhat better post release outcomes than inmates not participating in the program. On recidivism, it took much longer time for those who participated in the faith program to be re-arrested or re-imprisoned than those who did not participate in the program.

\section{Materials and Methods}

This study employed the use of qualitative method of research. Creswell [11] states that one of the characteristics of qualitative research is that it takes place in a natural setting "where participants experience the issue or problem under study." The natural setting paves the way for the researcher to have face to face interaction overtime. It brings to light descriptions of how people get things done and also the interactions that happens locally without any interference from the one researching. "Qualitative research asserts that data must be considered in its social context in order to reach a full and valid understanding" [13]. 
Bryman [14] in his book, social research methods posit that qualitative research method is best when the focus of a research is to explore the subject about which the researcher do not know much in advance and wants to grasp the motives and reasons which are usually unnoticed in standardized approaches. Qualitative research method was therefore ideal for this study since the researchers gathered information from the social setting of the prison environment and also needed to understand in details the processes within and without the prison walls contributing to recidivism.

The primary data for this study were gathered from interviews and observations. A semi-structured interview guide was used to solicit information from 30 purposively selected recidivist serving at the Kumasi Central Prisons. This was complemented with non-participant observations made within the prison yard and also during interview sessions. The 30 respondents comprised 15 males and 15 females to ensure a gender sensitive approach towards recidivism. The use of semi-structured interviews made it possible to probe further on information of great concern to the research objectives as the respondents respond to the questions. The interviews were mostly done late afternoons when the prisoners were less busy from their schedules. The process of interviewing took more than a month. The choice for purposive sampling procedure in the current study was based on Creswell [11] assertion that normally the idea behind the choice of qualitative research is to purposefully select participants, sites, documents or visual material that most assuredly will aid the researcher to understand the problem and the research question.

The primary data was also complemented with secondary data sources gathered from published annual prison reports, journals on prisons, newspaper articles, television and radio programs on prisons, church materials and reports on prisons. The data that was gathered was classified into similar responses. These were then analyzed and grouped into main themes.

These were linked together before meaning was made out of them. Direct quotation of respondents' views was also used to contextualize the discussions.

\section{Results and Discussion}

\subsection{Demographic Characteristics of Respondents}

As shown in Table 2, 50\% each of the respondents were females and males. Their ages ranges between 19 year and over 50 years, although a greater proportion (27\% each) of them were between the ages of 19 to 24 years and 31 to 35 years. Moreover, majority (67\%) of the inmates used for the study had basic education as their highest level of education with only one of the sampled respondents having tertiary education.

\subsection{Distribution of Criminal Categories}

The distribution of criminal categories of recidivists at Kumasi Central Prison is armed robbery, stealing, defilement, fraud, assault and substance abuse. As shown in Table 3, the study recorded the highest criminal offence as stealing, 
Table 2. Background characteristics of respondents.

\begin{tabular}{cccc}
\hline Variables & Levels & Frequency & Percentage \\
\hline \multirow{3}{*}{ Sex } & Male & 15 & 50 \\
& Female & 15 & 50 \\
& Total & 30 & 100 \\
$19-24$ & 8 & 27 \\
$25-30$ & 5 & 17 \\
$31-35$ & 8 & 27 \\
Age & $36-40$ & 4 & 13 \\
& $41-45$ & 1 & 3 \\
& $46-50$ & 3 & 10 \\
& Over 50 & 1 & 3 \\
& Total & 30 & 100 \\
& Basic & 20 & 67 \\
& Senior High & 9 & 30 \\
Tertiary & 1 & 3 \\
& Total & 30 & 100 \\
& & &
\end{tabular}

Source: Fieldwork, 2017.

Table 3. Distribution of criminal categories.

\begin{tabular}{ccc}
\hline Criminal Category & Frequency & Percentage (\%) \\
\hline Armed Robbery & 9 & 30 \\
Stealing & 11 & 37 \\
Defilement & 3 & 10 \\
Fraud & 2 & 7 \\
Assault & 4 & 13 \\
Substance Abuse & 1 & 3 \\
Total & 30 & 100
\end{tabular}

Source: Fieldwork, 2017.

and 37 percent of respondents fell into this category, whilst the least criminal offence was substance abuse accounting for 3 percent of the respondents.

\subsection{Previous Convictions and Sentencing}

The tendency to relapse into a previous criminal behavior is a main characteristic of recidivism. A criminal record of a person provides the summary of the types of offences, its frequency, methods and the number of months or years given by the law courts. Table 4 and Table 5 give information on previous convictions and frequency of commission of subsequent offences by categories on 
Table 4. Previous convictions.

\begin{tabular}{ccc}
\hline Previous Convictions & Frequency & Percentage (\%) \\
\hline First time & $\mathbf{0}$ & $\mathbf{0}$ \\
Second time & $\mathbf{2 4}$ & $\mathbf{8 0}$ \\
Third time & 6 & 20 \\
Total & 30 & 100 \\
\hline
\end{tabular}

Source: Fieldwork, 2017.

Table 5. Frequency of subsequent offences by categories.

\begin{tabular}{|c|c|c|c|}
\hline Number of Recidivist & First Offence/Sentencing & Second Offence/Sentencing & Third Offence/Sentencing \\
\hline 2017/KCP/RCI/01 & Stealing/12 months & Stealing/15 months & \\
\hline 2017/KCP/RCI/02 & Stealing/6 months & Defilement/7 years & \\
\hline 2017/KCP/RCI/03 & Stealing/4 months & Stealing/7 years & \\
\hline 2017/KCP/RCI/04 & Assault/1 year & Substance Abuse/2 years & Armed Robbery/4 months \\
\hline 2017/KCP/RCI/05 & Fraud/2 years & Assault/1 year & \\
\hline 2017/KCP/RCI/06 & Stealing/7 years & Fraud/3 months & \\
\hline 2017/KCP/RCI/07 & Armed Robbery $/ 3$ years & Armed Robbery/ 6 years & Armed Robbery/6 months \\
\hline 2017/KCP/RCI/08 & Stealing/6 months & Stealing/9 months & \\
\hline 2017/KCP/RCI/09 & Armed Robbery/8 months & Armed Robbery/6 months & \\
\hline 2017/KCP/RCI/10 & Stealing/6 months & Armed Robbery/8 months & \\
\hline 2017/KCP/RCI/11 & Stealing/1 year & Stealing/8 months & Assualt/6 months \\
\hline 2017/KCP/RCI/12 & Stealing/1 year & Stealing/10 years & \\
\hline 2017/KCP/RCI/13 & Defilement/6 month & Stealing/30 years & \\
\hline 2017/KCP/RCI/14 & Armed Robbery/6 months & Armed Robbery/2 years & \\
\hline 2017/KCP/RCI/15 & Stealing/12 months & Stealing/24 months & Stealing/14 years \\
\hline 2017/KCP/RCI/16 & Assault/18 months & Assault $/ 5$ years & \\
\hline 2017/KCP/RCI/17 & Assault/5 years & Assault/12 months & \\
\hline 2017/KCP/RCI/18 & Assault $/ 4$ years & Assault/9 months & \\
\hline 2017/KCP/RCI/19 & Stealing/4 months & Substance Abuse $/ 5$ years & \\
\hline $2017 / \mathrm{KCP} / \mathrm{RCI} / 20$ & Stealing/1 year & Assault/1 year & Assault $/ 5$ years \\
\hline $2017 / \mathrm{KCP} / \mathrm{RCI} / 21$ & Stealing/1 year & Defilement/7 years & \\
\hline 2017/KCP/RCI/22 & Assault/1 year & Defilement/14 years & \\
\hline $2017 / \mathrm{KCP} / \mathrm{RCI} / 23$ & Defilement/6 months & Defilement $/ 5$ years & \\
\hline 2017/KCP/RCI/ 24 & Armed Robbery/1 year & Armed Robbery $/ 5$ years & \\
\hline 2017/KCP/RCI/25 & Armed Robbery/6 months & Armed Robbery $/ 5$ years & \\
\hline $2017 / \mathrm{KCP} / \mathrm{RCI} / 26$ & Stealing/2 years & Stealing/4 years & \\
\hline $2017 / \mathrm{KCP} / \mathrm{RCI} / 27$ & Stealing/12 months & Stealing $/ 4$ years & Stealing/10 years \\
\hline $2017 / \mathrm{KCP} / \mathrm{RCI} / 28$ & Fraud/3 months & Fraud/6 months & \\
\hline $2017 / \mathrm{KCP} / \mathrm{RCI} / 29$ & Assault/12 months & Assault/2 years & \\
\hline 2017/KCP/RCI/30 & Fraud/6 months & Fraud/2 years & \\
\hline
\end{tabular}

Source: Fieldwork, 2017. 
the recidivists at Kumasi Central Prison. From Table 4, it can be revealed that, as many as 80 percent of the respondents stated that, it was their second time being in prison at the time of the survey. This implies a higher rate of recidivism.

Among the key offences subsequently committed by the recidivist were stealing, defilement, armed robbery, substance abuse, fraud, and assault with stealing and armed robbery dominating (see Table 5). It also be gleaned from the table that majority of the recidivist received higher sentencing on their second or third offences. This is an indication of the magnitude of the offences they committed and brings to the fore that recidivist becomes worse off after been released from prison.

\subsection{Risk Factors of Recidivism}

Three main themes emerge from the findings on the risk factors of recidivism. These are Societal, Institutional and Individual factors.

\subsubsection{Societal}

The causing factors grouped under societal are difficulty in re-integrating, unemployment and educational deficiencies.

1) Difficulty in re-integration

The word "integrate" is defined by the Cambridge International Dictionary of English as "to mix with and join society or a group of people, often changing to suit their way of life, habits and customs." Therefore, to re-integrate would mean to re-mix with and join society. The process involves re-entry. Re-entry comprises all activities and programming undertaken to prepare ex-offenders to return safely to the community as law abiding citizens. Alex, in his dissertation, cites Moore as identifying three stages in discharged prisoner re-entry [4]. The first stage is societal re-entry. This is where the discharged prisoner is freed from the prison life into the outside free world. This is crucial to every discharged prisoner because the success or otherwise of holding on to this freedom is largely dependent on the reception of the family of the person and those in the community in which the person lives. The second stage is re-entry as emergent social integration. Here, the discharged prisoner confidently counts on and benefits from emotional and material support from the society. The last stage is re-entry as social integration and that is where the ex-prisoner had actually settled and become active participants in daily community life. The finding from the study indicated difficulty in re-integrating due to dysfunctional family system.

The family, which is the first point of call after release from prison, is not functioning due to divorce of the parents. Kwame Bediako (not the real name) recounts his story ${ }^{1}$ :

"When I had served my sentence, I made up my mind to find a decent work to

${ }^{1} \mathrm{He}$ is 45 years old. The parents divorced when he was only 7 years. The mother left him and his two other brothers with their father. The father married a new woman and virtually neglected the three boys. He had to stop schooling at primary 6 . At age 15, he landed his first job as a cleaner with Johnsons Forex Bureau in Kumasi. He left the job because the income was not enough to care for him and his other two siblings. That move was the beginning of his woes. 
do for my daily living. I could not find any job and so I decided to go into stealing again to make my daily living. I was arrested when I stole someone's car and attempted to sell it. This time, I was handed 5 years imprisonment to be served at Kumasi Central Prison. At the prison, I made up my mind to learn a trade so I can earn decent income when I finish my sentence. However, before I could enroll in any trade, I was transferred to the prison at Salaga in the Northern Region. When I had served my sentence, the prison authorities at Salaga gave me only the lorry fare to Kumasi. In the bus in which I was travelling to Kumasi, I stole someone's bag but was caught. They gave me a good beating and wanted to hand me over at the nearest police station. I begged them and explained that I had just been released from prison and it was because I did not have any money on me apart from my lorry fare that is why I stole the bag. They then had pity on me and stopped their intended action. Life was difficult for me when I got to Kumasi as I had neither good education nor job. I decided to go into armed robbery but was arrested again together with my other accomplices in one of our trips and handed 10 years imprisonment to be served at Kumasi Central Prison. I was later transferred to the prison at Tamale to complete my sentence there.

Currently, I am serving another 10 years imprisonment at Kumasi Central Prison because after completing my earlier sentence at Tamale, I fell into armed robbery again. My life had been a misery as I keep falling back into stealing and armed robbery all the time. Life in the prison is not a joke but I have become used to it because the world outside these prison walls is harsher on me.

We are constantly harassed by the prison officers but what can we do?"

From the information given, it is clear that the divorce of the parents at that young age and his desire to take care of himself and his other two brothers has resulted in this present situation. The other issue to consider in the first point of call for the discharged prisoner is the death of the biological parents. Most of the time, the rest of the extended family members pay less attention to the children of the deceased parents. Yaw Abebrese (not the real name) recounts his story. ${ }^{2}$

"When I had served my sentence, I went to Manso Nkwanta to engage in small scale illegal miningagain. There also, I was arrested for trespassing on someone's land property. I was sentenced to 3 years imprisonment to be served at Kumasi Central Prison. However, after 2 months into the sentence, I broke jail and fled. I broke jail because I was bitter at how the police handled the case. The police should have arrested my boss also but they allowed him to run away and used me as a scape goat.

I had to earn my daily food but I did not know what to do. I decided to go into stealing. One day, I stole someone's motor cycle but was arrested and sentenced to 2 years imprisonment to run concurrently with the earlier 3 year sentence that I broke jail. Currently, I am serving the 3-year sentence. I don't know what life

${ }^{2} \mathrm{He}$ is 32 years old. Both parents died in one year interval when he was 14 years. He had to carry cocoa at Goaso in the Brong Ahafo region to take care of himself. He desired to complete basic education but dropped out at Junior High two. He could no longer combine work with schooling. His wanderings took him to Accra, Tarkwa Nsoayam, Manso Nkwanta and Kumasi. 
holds for me outside there. How would I live when my time is up and I am released from here? I have no one to look up to. Maybe I have to continue with the stealing".

From the information above, it is clear he has resigned his fate to perpetually be in prison. In addition to the failure at the very first stage, there is also the issue of stigmatization. Stigmatize is to label or set a mark of disgrace upon someone. The prisoners intimated that the common mark of disgrace that is normally set upon them is the term "jail man" or "jail woman." Instead of them being called by their known names, they are rather called by the stated term by the family, community and society. It therefore follows logically that if such person suffers from non-acceptance from the family, community or the society at large, then the released prisoner contemplates going back to the prison again.

2) Employment

Discharged prisoners are not able to be gainfully employed because some lack requisite skills. All prisoners participating in the study entered "NO" when asked whether they undertook any rehabilitation program such as masonry, carpentry, weaving or any other kind during their last imprisonment or their current imprisonment. Thus, they are unable to get any jobs or any meaningful job if any because they have no skills. However, those with skills already also suffer from been gainfully employed due to their criminal records. As indicated earlier, the stigma of having been in prison before normally follows them and so employers are either afraid or are not sure of the level of trust to give to these ex-offenders and so therefore refuse them employment. They do not have startup capital to start their own business. Not being gainfully employed means no income and therefore inability to provide for personal needs let alone provide for others if the discharged prisoner has wife and children. A third-time recidivist recounts what happened to him when he could not afford to rent a room.

"When I had finished serving my sentence, I resolved never to return to prison again. I chose to continue being a driver's mate. I also went in search of any uncompleted building whose owner would allow me to occupy one of the rooms in exchange for keeping the place tidy. My search took me to an uncompleted house at Fumesua. When I entered the house, an occupant there came out and asked me my mission. I explained myself but that person challenged me that I was a thief on a spy mission. I explained to the person that I have been in prison before and know what is there and so have resolved never to go back there. My mention of being in prison before made him more suspicious of me. The person raised alarm. I was arrested, sent to court and sentenced to 3 months imprisonment to be served at Kumasi Central Prison".

As indicated in Table 1, a greater percentage of the participants in this study had their educational level to be at the basic level, followed by primary and then tertiary being the least. Informal interaction with some of them indicated they were not given the moral and financial support by either their immediate or remote family hence curtailing their education prematurely. Situating the findings under difficulty in re-integrating in existing literature, Maltz [15] has indicated 
that failure of the society to provide for the individual is a contributory factor to recidivism.

In the context of what had been discussed, the failure of the society was in respect of how they make it difficult for ex-offenders to reintegrate, the absence of job opportunities or any other source of income for them and the very low level of education making them almost non-competitive in the job market. "Whereas strong stigma deters an un-convicted individual from committing crimes, it simultaneously enhances recidivism of a convicted and stigmatized offender" [16]. In determining the predictors of recidivism, Gendreau et al. [17] had already been cited that criminogenic needs produced higher correlations with recidivism. Criminogenic needs are those when provided, are likely to prevent re-offending. These include family and society acceptance, provision of employment, accommodation, reliable income and all that is needed for basic human living. In addition, an earlier finding has shown that ex-offenders were more likely to become recidivists if they are unemployed after release from prison [18]. Consistent with findings from [19] in earlier studies was that educational deficiencies were significant predictor of recidivism. The uneducated or under educated were likely to be imprisoned earlier than those who had a high level of education.

\subsubsection{Institutional}

The statements quoted below are the stated mission and vision of the Ghana Prison Service respectively:

The Ghana Prison Service is tasked with the safe custody of convicted persons from the courts as well as the provision of reformation and rehabilitation programmes for their successful resettlement into society. Our cherished values are humanity, vigilance and fortitude.

Our vision is to transform the Ghana Prison Service into a highly efficient correctional service, managed by a well-trained, disciplined and motivated staff

In spite of the focus of the service into being an efficient correctional institution championing the reformation and rehabilitation of the convicted person for successful resettlement into the society, the institution unfortunately contributes to recidivism in the areas of cell population, conduct of some Prison Officers and prisoners not adequately reformed.

1) Cell Population

The researcher was informed that in the early years of the establishment of Kumasi Central Prison, there were separate cells for recidivists, first time offenders and those on remand. However, over the years, the prison population has swelled up uncontrollable. As stated earlier, a prison with official capacity of 600 inmates now accommodates almost 2000 inmates. Thus, recidivists are mixed up with first time offenders in the various cells in the prison leading to "character contamination". What character contamination means in this context is where a recidivist teaches a first-time offender ways and methods of committing crime. At the time that the first-time offender is discharged, he would have 
gathered enough "lectures notes" on how to play it tough the next time. Thus, if survival in the open world becomes tough, all that is needed is for such a person to recall the lecture notes, involve in crime and eventually get back to prison again.

2) Conduct of Some Prison Officers

One of the findings of the study was that some of the Prison Officers involve some of the inmates in trafficking of prohibited substances whilst they are in the prison thus making them more criminal. Such prohibited substances such as marijuana and alcohol are traded in by some Prison Officers. Obviously, such Prison Officers do so for their own personal gains. As the inmate become actively involved, the interest goes up and eventually such an inmate is discharged a worse person than before. The probability of re-offending therefore becomes very high.

3) Not Adequately Reformed

As indicated earlier, the way recidivists are mixed up with first time offenders and the conduct of some Prison Officers impact negatively on the reformation and rehabilitation of prisoners. The other issue affecting the reformation of prisoners is the amnesty the government grants to prisoners on such days as Independence and Republic Day celebrations. Some are of the view that such prisoners do not actually use such freedom positively. Kofi Clinton (not the real name) recounts how he did not make good use of the amnesty he gained. ${ }^{3}$

"I was again arrested and charged for unlawful entry into someone's shop. I was handed 4 years imprisonment to be served at Kumasi Central Prison. However, I did not finish this sentence when I was granted amnesty by the government. Unfortunately, I did not make good use of this freedom.

I had now become 'used' to stealing and have learnt more tricks from my cell mates during my last sentence. My grandfather who is a retired soldier had some kente cloths. I stole and sold them. He suspected me and got me arrested. After I had been given some hefty slaps, I confessed to the stealing. My grandfather insisted to the Police that I should be sent to jail again to learn sense because he does not think I have learnt any lessons yet. I was handed 3 years imprisonment to be served at Kumasi Central Prison."

It is clear from the above that he did not make good use of the freedom he gained. He was tempted to put into practice ways of stealing he had learnt from his cell mates. Consistent with earlier findings by [15] which had been cited is the failure of the institution to ensure adequate rehabilitation of the prisoner therefore leading to recidivist behavior. Also, as discussed elsewhere [20] that associations with criminal friends were statistically significant predictor of criminal behavior.

\subsubsection{Personal}

The personal factors that contribute to recidivism include associating with bad

${ }^{3} \mathrm{He}$ is 26 years old. His father is a Policeman. The mother is a Priestess at African Faith Tabernacle Church. Though he claims the mother was very concerned about him living a decent life, he still fell to his own ways. 
friends outside the prison, low interest in participating in rehabilitation and transformational programmes, inability to cope with challenges in the society and substance abuse.

1) Association with Bad Friends

It has been stated already that when discharged prisoners are not welcomed well and accepted by their family and the community, they tend to contemplate returning to the prison. They now look out for the friends they made whilst in prison or frequent places where the conduct of the people there are anti-social and violent thereby exposing such people to criminality. Thus, in such context, the probability of the discharged prisoner to be involved in crime and be re-arrested would be very high because bad friends inevitably lead to bad decisions. Kwadwo Babone (not the real name) recounts his story ${ }^{4}$.

"Some friends introduced me to armed robbery and so I used the driving in armed robbery operations. I was arrested sometime in 2013 and given 3 months imprisonment to be served at Kumasi Central Prison. When I had served my sentence, $I$ was again arrested in a robbery case at Bantama and handed 4 years imprisonment to be served at Aman from Prison Camp. Having served 2 years 2 months, the Church of Pentecost at Trede made an appeal on my case and I was freed by the court in July 2016. My parents received me warmly and admonished me to work and earn a decent living. However, I fell into armed robbery again with some of the friends I made at Aman from Prison Camp. I was arrested in a robbery case at Trede and sentenced to 14 years imprisonment.

Currently, I am serving this sentence at Kumasi Central Prison. I could not reform due to the bad company I associated with. Though the prison conditions such as overcrowding, heat in the cells and constant harassment by the prison officers are there, I am just unable to free myself from the company of these my friends. I feel sad I have disappointed my parents."

It is clear from the information above that keeping bad friends inevitably results in recidivist behavior.

2) Low interest in rehabilitation

There are many rehabilitation programmes at Kumasi Central Prison. These include learning vocational skills such as masonry, carpentry, weaving or schooling to improve on one's education to acquire Junior High Certificate or Senior High Certificate. But when asked about the level of participation in such programmes, almost all the Prison Officers who participated in the study indicated low level. Probed further, the finding was that most of the inmates were not happy about the quality of the food given them at the prison. Besides that, the ration is mostly not adequate to fill the stomach. Therefore, most inmates prefer to go out and work for those companies that have requested for the services of the inmates from the prison authorities. When the prisoners have ren-

${ }^{4} \mathrm{He}$ is 34 years old. The parents are active members of the Church of Pentecost at Trede. His passion was to be a Policeman. When he consistently did not gain entry into the police training school, he went into small scale illegal mining. Then he left and went into driving and was using that in robbery operations. 
dered the required services to the company in question, some of the companies give gifts to these prisoners aside the official payment to the prison authorities. These gifts, which sometimes may be cash is what they use to buy personal items such as food, soap, toothpaste, toothbrush and others. Some prisoners also lodge with the prison treasury, any cash in excess they have with them for safe keeping so that on the day of discharge, they might carry them away. It therefore stands to reason that when such persons are discharged, they have neither requisite vocational skill to do their own business nor improved education to be employed. This situation does not enable them to cope with the challenges in the society and so eventually return to prison.

3) Substance abuse

Some of the inmates are in the prison because of substance abuse such as smoking or trading in marijuana, crack, cocaine and others. Due to the fact that these substances are addictive, those involved in the use of some of these substances find it difficult to abstain from them. Such persons may continue this practice when in prison with the connivance of some Prison Officers. Thus, when such persons are discharged, they soon find themselves back to the prison. Situating the findings under personal factors into existing literature it had already been cited that associations with criminal friends were statistically significant predictor of criminal behavior [20]. Holsinger had also been cited that individuals who had persistent and favorable attitudes, feelings or thoughts towards crime, by making friends of criminals committed more crime. The Bible is emphatic in 1 Corinthians 15:33 that "Do not be deceived: Evil company corrupts good habits." In their studies on the predictors of recidivism, Gendreau et al. [17] had been cited that substance abuse was among the most potent predictors of recidivism. Consistent with the findings of Maltz [15] on the risk factors of recidivism, there is failure at the individual level to stay out of trouble, to escape arrest and conviction and to take advantage of a correctional programme as an inmate of a correctional institution.

\section{Conclusion}

The study presents the major risk factors associated with recidivism from the perspective of three broad interrelated themes, which are from the societal, institutional and individual point of views. Accounts of individual recidivists are elicited and discussed in the context of existing literature. What causes discharged prisoners to return to prison as revealed by the study included among others failure of their family to accept them, stigmatization by the community and society at large, unemployment, association with bad friends and first-time offenders mixed up with hardened criminals in the prison. The study concludes that despite the various efforts aimed at rehabilitating prison inmates in Ghana and specifically the Kumasi Central prisons, there are pull and push factors that make them to go back into their old ways. Among the risk factors of recidivism identified by the study, a greater number of them have to do with activities outside the prison walls. The need to consider policies and efforts outside the prison 
walls in reducing recidivism can therefore not be overemphasized. Institutional support systems should be created and existing once enhanced. There must be active education of the family and the society at large on the need to support discharged prisoners to be able to successfully reintegrate into the society. Furthermore, Family Support Groups could be formed to find and share common answers to common problems to reduce recidivism. Convicts could be assigned to Parole Officers just before their discharge to enforce and monitor compliance of court orders to sustain code of Good Behavior within society. The legislature may have to examine again the Act governing Prison Regulations, Administration and Management, focusing on "Repeat Offenders" to reduce recidivism in the country.

\section{Conflicts of Interest}

The authors declare no conflicts of interest regarding the publication of this paper.

\section{References}

[1] Merriam Webster Dictionary (2016) Recidivism. https://www.merriamwebster.com/dictionary/recidivism

[2] Gleissner, J.D. (2016) Recidivism-Its Causes and Cure. http://www.corrections.com/news/article/30720-recidivism-its-causes-and-cure

[3] Deady, C.W. (2014) Incarceration and Recidivism: Lessons from Abroad. http://www.salve.edu/search/all/incarceration and recidivism

[4] Antwi, A. (2015) Social Reintegration of Offenders and Recidivism in Ghana. PhD Dissertation, University of Ghana, Accra.

[5] Agalga, J. (2017) Recidivism on the Increase in Ghana Due to Feeling of Rejection. https://gbcghana.com/1.9871203

[6] International Centre for Prison Studies (n.d) World Prison Brief. http://www.prisonstudies.org

[7] Mensah-Tsotorme, E. (2016) Justice for All Had Reduced Prison Population-CJ. The Ghanaian Times, 15 December 2016.

[8] Byron, R.J. (2003) The Inner Change Freedom Initiative. Philadelphia Centre for Research on Religion and Urban Civil Society, University of Pennsylvania, 48-51.

[9] Gerace, A. and Day, A. (2010) Criminal Rehabilitation: The Impact of Religious Programming. Journal of Psychology and Christianity, 29, 317-326.

[10] Lavigine, et al. (2007) Evaluation of Florida Faith and Character Based Institutions. Research Report, Urban Institute: Justice Policy Center.

http://www.researchgate.net

[11] Creswell, J.W. (2009) Research Design: Qualitative, Quantitative, and Mixed Methods Approaches. Thousand Oaks, California.

[12] Byron, R.J. (2004) Religious Programs and Recidivism among Former Inmates in Prison Fellowship Programs: A Long-Term Follow-Up Study. Justice Quarterly, 21, 334. http://www.tandfonline.com

[13] Aagaard-Hansen, J. and Yoder, S.P. (2007) Buying Research: A Customers' Guide. University of Copenhagen, Denmark. 
[14] Bryman, A. (2004) Social Research Methods. 2nd Edition, Oxford University Press, Oxford.

[15] Maltz, M. (1984) Recidivism. Maltz Publishers, New York.

[16] Funk, P. (2003) On the Effective Use of Stigma as a Crime Deterrent. European Economic Review, 48, 715-728. http://www.sciencedirect.com https://doi.org/10.1016/j.euroecorev.2003.11.003

[17] Gendreau, P., Little, T. and Goggin, C. (1996) A Meta-Analysis of the Predictors of Adult Offender Recidivism: What Works. Journal of Criminology, 34, 588-590.

[18] Nally, et al. (2016) Post Release Recidivism and Employment among Different Types of Released Offenders: A 5-Year Follow-Up Study in the United States. International Journal of Criminal Justice Sciences, 9, 28.

http://www.sascv.org.nallyetalijcjs2014vol19issue1.pdf

[19] Tenibiaje, J.D. (2013) Educational Attainment and Peer Group Influence as Predictors of Recidivism. International Review of Social Sciences and Humanities, 5, 30-37. http://www.irssh.com

[20] Daniel, B., Hyland, P., Pedziszczak, J. and Kielkiewicz, K. (2012) Criminal Attitudes, Recidivist Behaviour and the Mediating Role of Associations: An Empirical Investigation within a Prison Sample of Violent Offenders. Europe's Journal of Psycholo$g y, 8,26-28$. 